\title{
BIOEDUSCIENCE
}

ISSN: 2614-1558

http://journal.uhamka.ac.id/index.php/bioeduscience

\section{Biological Aspects of Waanders's Hard-lipped Barbs (Osteochilus waandersii) in Tambatan River, North Sumatera, Indonesia}

\author{
Siti Jurniah Nasution ${ }^{1}$, Rivo Hasper Dimenta ${ }^{1^{*}}$
}

${ }^{1}$ Biology Education of Study Programs, Universitas Labuhanbatu, Jl. S.M Raja No. 126 A, Rantauprapat, Kabupaten Labuhan Batu, Sumatera Utara, Indonesia, 21418

*Correspondent Email: rivohd11@gmail.com

Check for updates

\section{ARTICLE INFO}

\section{Article history:}

Received: 03 Apr 2021

Accepted: 09 Aug 2021

Published: 30 Aug 2021

\section{Keywords:}

Gonad Maturity Level;

Growth pattern;

Osteochilus waandersii;

Tambatan River;

\section{Kata kunci:}

Osteochilus waandersii;

Pola pertumbuhan;

Sungai Tambatan;

Tingkat Kematangan Gonad;

\section{A B S T R A C T}

Background: Waanders's hard-lipped barbs or scientifically known as Osteochilus waandersii belong to the family Cyprinidae with the potamodromous category. This fish can be found in the Tambatan river, and it has the potential for commercial consumption or ornamental fish. Methods: This study was conducted in the Tambatan river from November to January 2021. The determination of three research stations was carried out using a purposive sampling method. Sampling was undertaken using cast nets. Furthermore, data analyzed were growth patterns, condition factors, and gonad maturity levels. Results: The growth patterns of male (1.944) and female (2.379) Osteochilus waandersii were in a harmful allometric category. Besides, The Fulton's condition factor for male fish ranged from $0.42-3.43$ with an average of 1.05, while that for female fish ranged from 0.59 - 3.67 with an average of 1.47. The result of the observation on the gonad maturity level for male and female $O$. waandersii in the Tambatan river indicated that they were dominated by fish with gonad maturity stage I (immature). Conclusions: Waanders's hard-lipped barbs 0 . waandersii found were in the stage towards the mature level.

Aspek Biologi Waanders's hard-lipped barb (Osteochilus waandersii) di Sungai Tambatan, Sumatera Utara, Indonesia

\section{A B S T R A K}

Background: Waanders's hard-lipped barbs atau secara ilmiah dikenal sebagai Osteochilus waandersii termasuk dalam famili Cyprinidae dengan kategori potamodromous. Ikan ini dapat ditemukan di sungai Tambatan dan memiliki potensi untuk konsumsi komersial atau ikan hias. Metode: Penelitian ini dilakukan di sungai Tambatan pada bulan November hingga Januari 2021. Penentuan tiga stasiun penelitian dilakukan dengan menggunakan metode purposive sampling. Pengambilan sampel dilakukan dengan menggunakan jaring cor. Selanjutnya data yang dianalisis adalah pola pertumbuhan, faktor kondisi, dan tingkat kematangan gonad. Hasil: Pola pertumbuhan Osteochilus waandersii jantan $(1,944)$ dan betina $(2,379)$ termasuk dalam kategori alometrik negatif. Sedangkan faktor kondisi Fulton untuk ikan jantan berkisar antara 0,42 - 3,43 dengan rata-rata 1,05, sedangkan untuk ikan betina berkisar antara 0,593,67 dengan rata-rata 1,47 . Hasil pengamatan tingkat kematangan gonad $O$. waandersii jantan dan betina di sungai Tambatan menunjukkan bahwa mereka didominasi oleh ikan dengan kematangan gonad tahap I (belum matang). Kesimpulan: Waanders's hardlipped barbs yang ditemukan $O$. waandersii berada dalam tahap menuju tingkat dewasa. 


\section{Introduction}

The Waanders's hard-lipped barb (Osteochilus waandersii) is a freshwater fish belonging to the family Cyprinidae. Its morphometric and meristic characteristics are included in the order Cypriniformes, family Cyprinidae, genus Osteochilus, and species Osteochilus wandersii. Based on its morphology, this fish has a blackish back (Kottelat et al., 1993). All fins are yellow. The base of the dorsal and tail fins is black (Sukmono \& Margaretha, 2017). Furthermore, this fish has a clear black stripe from the gill to the tip of the tail. It also has 12 - 13 forked dorsal. In addition, its tail fin, back fin, pectoral fin, and pelvic fins have light orange or red color (Fishbase, 2021). O. waandersii belongs to the potamodromous category, meaning that this fish can live in freshwater only (Riede, 2004).

In Indonesia, this fish has several names, including kujam garis in Jambi and its surrounding (Sukmono \& Margaretha, 2017). In Czechia, this fish is known as tvrdoretka waandersova (Hanel, L. \& Novák, 2002). In Estonia, it is called waandersi luumokk (Biodiversity, 2015). Besides kujam garis in Jambi, it is also known as bantak surik/bantak batu in several region in Indonesia (Kottelat, \& M. Widjanarti, 2005). Cambodian people call this fish trey kros (Rainboth, 1996). In Laos, it is called pa khang lai gnai/pba kang lai (Baird, 1998). In China, this fish is known as wa shi shi wen chun yu (Wu et al., 1999).

Distribution $O$. wandersii spread across several countries, including Thailand (the Mekong river, Chao Phraya), to the Malay peninsula, Sumatra, and Borneo (Kottelat, 1998). In addition, this fish can also be found in Vietnam (Kottelat et al., 1993), Cambodia, and Laos (Kottelat, 1998). The habitat of this fish is large freshwater rivers with fast currents and rocky \& gravel substrates (Kottelat, 1998). It is a species of omnivore fish that eats algae, mosses, and small animals. In other words, this fish can be called detritus - decomposers of organic waste from plants and animals (Rainboth, 1996).

Several studies have been conducted on this topic. Septian et al. (2020) studied the distribution of Osteochilus sp. in Kapuas Hulu District. Soetignya et al. (2020) investigated the reproductive aspects of 0 . waandersii. Samuel \& Suryati (2014) and Atminarso et al. (2015) measured the growth parameters of 0 . waandersii. Adiansyah \& Samuel (2017) observed the mortality and growth patterns of Osteochilus Sp. William \& Beamish (2006) studied the habitat of 0 . waandersi from the family Cyprinidae.

In this study, the chosen research location is the Tambatan river. It is one of the tributaries, administratively located at Bandar Durian village, North Labuhanbatu. This river is widely used by the community for many activities. The flow of this river disembogues into the Kualuh river. In addition, the community activities around this river are fishing for filling their daily necessities and mining sand \& stone traditionally. These various activities are presumed to be the cause of the decline in the distribution of the population of $O$. waandersii.

To date, not much information has been known about the bioecological aspects of the Waanders's hard-lipped barbs ( $O$. waandersii) in the Tambatan river because a study related to this topic is rarely conducted. Therefore, this study aims to present information on biological aspects, such as growth patterns, condition factors, and the level of gonad maturity, of Waanders's hard-lipped barbs (O. Waandersii). Data presented in this study are expected to be able the initial information to manage the potential of freshwater fisheries resources in the future.

\section{Methods}

\section{Research Setting}

This study was conducted from November 2020 to January 2021 in the Tambatan river, Bandar Durian Village, North Labuhanbatu, North Sumatra. The determination of sampling stations was carried out using a purposive sampling method, in which this method allows the sampling points to be determined based on specific considerations to make the obtained data more representative.

\section{Samples}

Sampling was conducted once a month from 10:00 a.m. to 3:00 p.m. There were three research stations in this study. They were determined using the Global Positioning System (GPS). The description of information of sampling station (Table 1.), Station 1 was located at $2^{\circ} 21^{\prime} 28.37^{\prime \prime} \mathrm{N}$, 99 $41^{\prime} 20.38^{\prime \prime} \mathrm{E}$, this station is in Dusun II Jarinjing near community settlements. At this station, the substrate of the river channel primarily consists of sand with a calm current and is surrounded by community-owned oil palm plantations. Station 2 was located at $2^{\circ} 21^{\prime} 42.58^{\prime \prime} \mathrm{N}$, 99.40'40.88" E. This station is still in Dusun II Jarinjing but far from community settlements. At this station, the substrate of the river channel mostly consists of rock with a moderate current and is surrounded by woods. Station 3 was located at $2^{\circ} 21^{\prime} 38.26^{\prime \prime} \mathrm{N}, 99^{\circ} 40^{\prime} 52.18^{\prime \prime}$ E. This station is also in Dusun II Jarinjing, far from community settlements. At this station, the substrate of the river channel mostly consists of sand and rock with a moderate current. Data analysis was carried out in the Ecology Laboratory, Faculty of Teacher Training and Education, Labuhanbatu University. The object of this study was Waanders's hardlipped barbs ( $O$. waandersii) from the Tambatan river. Sampling was conducted for three months, from November 2020 to January 2021. 


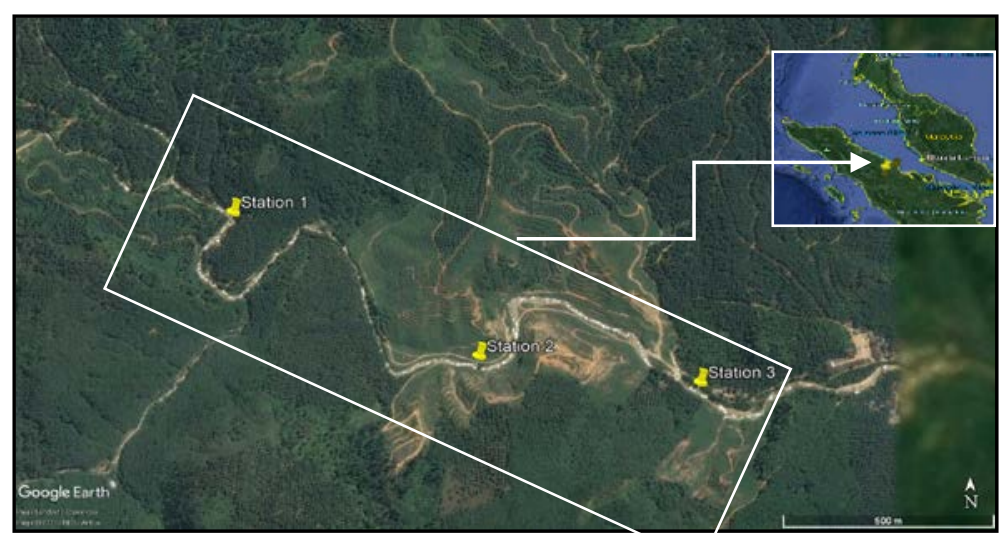

Figure 1. Study site of sampling in the Tambatan river, Labuhanbat

Table 1. Description of Sampling Location

\begin{tabular}{|c|c|c|}
\hline Location & $\begin{array}{c}\text { Ordinate } \\
\text { Point }\end{array}$ & Description \\
\hline $\mathrm{St}$ & $\begin{array}{l}2^{\circ} 21^{\prime} 28.37^{\prime \prime} \\
\mathrm{N}, \\
99^{\circ} 41^{\prime} 20.38^{\prime \prime} \\
\mathrm{E}\end{array}$ & $\begin{array}{l}\text { this station in Dusun Jarinjing } \\
\text { II is near community } \\
\text { settlements. This station has a } \\
\text { substrate of river mostly } \\
\text { consisting of sand with a calm } \\
\text { current and surrounded by oil } \\
\text { palm plantations }\end{array}$ \\
\hline Sta & $\begin{array}{l}2^{\circ} 21^{\prime} 42.58^{\prime \prime} \\
\mathrm{N} \\
99.40^{\prime} 40.88^{\prime \prime} \\
\mathrm{E}\end{array}$ & $\begin{array}{l}\text { This station is far from } \\
\text { community settlements. At this } \\
\text { station, the substrate of the } \\
\text { river mostly consists of rock } \\
\text { with a moderate current and is } \\
\text { surrounded by woods }\end{array}$ \\
\hline Stati & $\begin{array}{l}2^{\circ} 21^{\prime} 38.26^{\prime \prime} \\
\mathrm{N}, \\
99^{\circ} 40^{\prime} 52.18^{\prime \prime} \\
\mathrm{E}\end{array}$ & $\begin{array}{l}\text { This station, the substrate of } \\
\text { the river channel mainly } \\
\text { consists of sand and rock with } \\
\text { a moderate current }\end{array}$ \\
\hline
\end{tabular}

\section{Instruments}

The samples were caught using cast nets with a diameter of $2 \mathrm{~m} \&$ a mesh size of $1 / 2$ inch. In addition, other tools used in this study were millimetre paper, aquarium, camera, ruler, and callipers. Samples of fish caught were weighted (gram) using a digital scale with an accuracy of 0.01 grams and measured their length $(\mathrm{cm})$ using callipers with an accuracy of $0.01 \mathrm{~mm}$.

\section{Research Procedure}

Sampling was carried out during the day with cast nets. The nets were thrown 20 times at each station. The captured samples were put into an aquarium to obtain a clear description of the fish. They were then put into a styrofoam box and sent to the Ecology Laboratory of Labuhanbatu University for further identification process, including morphometric measurements, body weight measurements, and gonad maturity level observations (Kottelat et al., 1993).

\section{Data Collection and Data Analysis}

\section{Growth Pattern}

The growth pattern was calculated using the formula proposed by (King, 1995).

$$
\mathrm{W}=\mathrm{aL}^{\mathrm{b}}
$$

Where: $\mathrm{W}$ is the total weight (g) of the fish; $\mathrm{L}$ is the total length $(\mathrm{cm})$ of the fish; the coefficients $a$ and $b$ are the constants of the growth pattern formula.

The applied growth pattern categories are as follows. (A) If $b$ is equal $(=)$ to 3 , then the growth is balanced between length and weight (isometric). (B) If $b$ is lower $(<)$ than 3 , then the growth in length is more dominant than the growth in weight (negative allometric). (C) If $b$ is higher $(>)$ than 3 , then the growth in weight is more dominant than the growth in length (positive allometric).

\section{Observation of the Gonad Maturity Level (GML)}

This observation referred to Table of the Gonad Maturity Level for Male and Female $O$. waandersii in Rivers.

Table 2. Categories of Gonad Maturity Level (Hayati, 2018)

\begin{tabular}{|c|c|c|}
\hline GML & Males & Females \\
\hline I & $\begin{array}{l}\text { The gonads are not yet } \\
\text { developed. }\end{array}$ & $\begin{array}{l}\text { The gonads are not yet } \\
\text { developed. }\end{array}$ \\
\hline II & $\begin{array}{l}\text { The surface of the } \\
\text { testicles is slightly } \\
\text { serrated and milky } \\
\text { white. }\end{array}$ & $\begin{array}{l}\text { Ovaries are reddish } \\
\text { yellow, and the eye } \\
\text { cannot see eggs. }\end{array}$ \\
\hline III & $\begin{array}{l}\text { The surface of the } \\
\text { testicles is serrated and } \\
\text { white. Furthermore, the } \\
\text { blood vessels are still } \\
\text { visible. }\end{array}$ & $\begin{array}{l}\text { Morphologically, the } \\
\text { eggs in the ovary are } \\
\text { yellow, and the grains } \\
\text { begin to appear. }\end{array}$ \\
\hline IV & $\begin{array}{l}\text { The testicles look like } \\
\text { those in GML III, but } \\
\text { clearer, and blood } \\
\text { vessels are not visible. }\end{array}$ & $\begin{array}{l}\text { The ovaries are getting } \\
\text { bigger. The eggs are } \\
\text { yellow and easy to } \\
\text { separate. However, the } \\
\text { oil grains are not } \\
\text { visible. }\end{array}$ \\
\hline V & $\begin{array}{l}\text { The testicles on the } \\
\text { back deflated and near }\end{array}$ & $\begin{array}{l}\text { The ovaries are } \\
\text { wrinkled, the walls are }\end{array}$ \\
\hline
\end{tabular}


the outlet were still thick, and the side eggs filled. are located near the release.

\section{Condition Factor Analysis}

In this study, the relative weight (Wr) and the condition factor coefficient were used to calculate the condition factor for each sample. To calculate the relative weight (Wr), the researchers applied an equation proposed by Rypel \& Richter (2008).

\section{$\mathrm{Wr}=\mathrm{W} / \mathrm{Ws} \times 100$}

Where: $\mathrm{Wr}$ is relative weight; $\mathrm{W}$ is the weight of each sample; Ws is the prediction of the standard weight of the same sample as it is calculated from the combined lengthweight regression over the range between species.

\section{$\mathbf{K}=\mathbf{W L}^{-3} \times 100$}

Where: $\mathrm{K}$ is the condition factor; $\mathrm{W}$ is the weight $(\mathrm{g})$; $\mathrm{L}$ is the length $(\mathrm{cm}) ; 3$ is the length coefficient to test whether the $\mathrm{K}$ value tends to be close to 1 . According to Morton \& Routledge (2006), the fish population is in good condition if the $\mathrm{K}$ value is more than 1 .

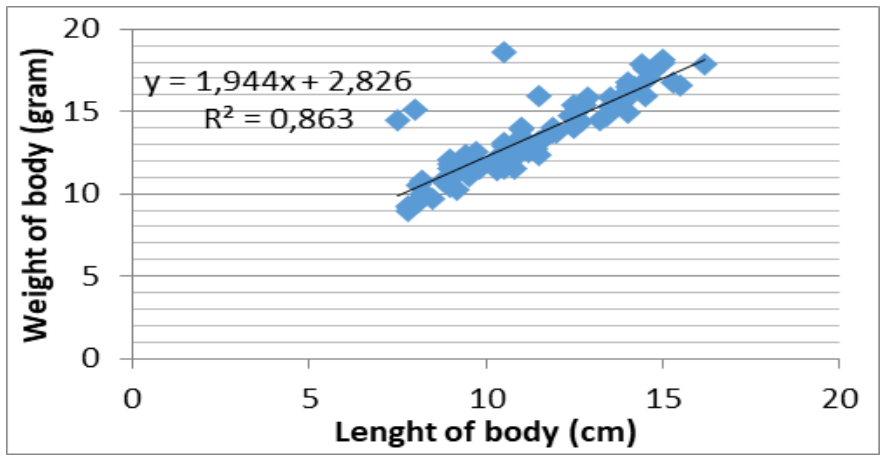

Figure 2a. The growth pattern of male $O$. waandersii

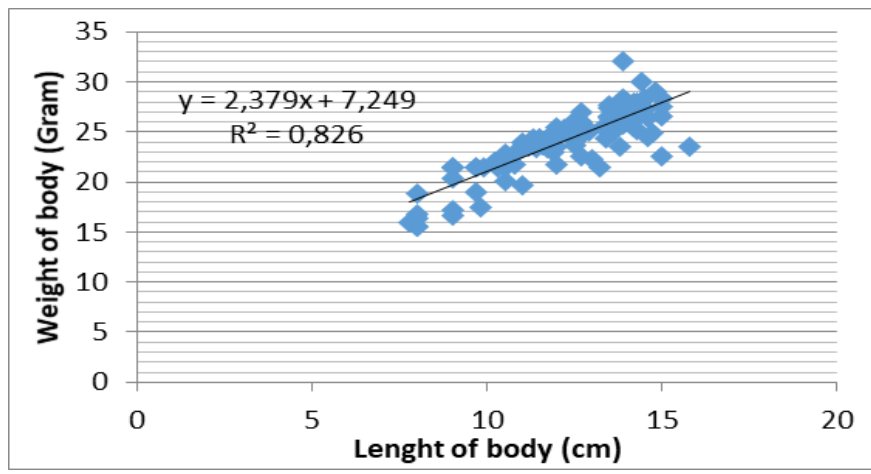

Figure $\mathbf{2 b}$. The growth patterns of female O.waandersii

Table 3. Biological parameters observed on 0 . wandersii

\begin{tabular}{lcccc}
\multicolumn{1}{c}{ Parameters } & Males & Average & Females & Average \\
\hline Total length (cm) & $7.5-16.2$ & 11.52 & $7.80-15.80$ & 5.61 \\
Measured weight of fish, W (grams) & $9.0-18.6$ & 13.72 & $15.50-32.00$ & 4.82 \\
Predicted weight, Ws (grams) & $9.09-18.76$ & 13.61 & $7.17-20.59$ & 14.17 \\
Relative weight, Wr & $62.74-111.45$ & 99.40 & $39.61-87.65$ & 58.29 \\
Fulton condition factor, K & $0.42-3.43$ & 1.05 & $0.59-3.67$ & 1.47 \\
The coefficient of determination $\left(\mathrm{r}^{2}\right.$ ) & 0.863 & - & 0.826 & - \\
$b$-Value (Growth Pattern) & 1.944 & - & 2.379 & - \\
\hline
\end{tabular}

${ }^{*}$ GML=Gonad Maturity Level

\section{Results}

\section{The Condition Factor}

Based on the analysis results, the length (TL) of $O$. waandersii ranged from $7.5-16.2 \mathrm{~cm}$ for males and 7.80 $15.80 \mathrm{~cm}$ for females. The weight (W) ranged from 9.0 18.6 grams for males and 15.50 - 32.00 grams for females. Weight prediction (Ws) ranged from 9.09 - 18.76 for males and 7.17 - 20.59 for females. The relative weight (Wr) ranged from 62.74 - 111.45 for males and 39.61 - 87.65 for females. The Fulton's K condition factor ranged from 0.42 3.43 for males and $0.59-3.67$ for females. The coefficient of determination $\left(r^{2}\right)$ was 0.863 for males and 0.826 for females. For the last, the b value was 1.944 for males and 2.379 for females.

\section{Growth Pattern}

The results of data analysis on the growth pattern of Waanders's hard-lipped barbs (O. waandersii) indicated that the obtained $b$ value was 1.944 for males and 2.379 for females. For more detailed data, it can be seen in the figures $2 \mathrm{ab}$. The data concerning the growth patterns of male and female 0 . waandersii in the Tambatan river indicated a negative allometric relationship because the value of $b$ is < 3 , meaning that the growth in length is faster than the growth in weight.

\section{Gonad Maturity Level (GML)}

This study analysed the gonad maturity level of male and female 0 . waandersii, starting from the immature level (stage I) to maturity stage $V$, as shown in Figures $3 \mathrm{a}$ and $3 \mathrm{~b}$. The total of male $O$. waandersii caught throughout this study were maturity stage I (immature) 47 individuals $/ \mathrm{m}^{2}$, gonad maturity stage II (19 ind $/ \mathrm{m}^{2}$ ), with a maturity stage III (12 ind $\left./ \mathrm{m}^{2}\right)$, maturity stage IV $\left(6 \mathrm{ind} / \mathrm{m}^{2}\right)$, and maturity stage $\mathrm{V}\left(2 \mathrm{in} / \mathrm{m}^{2}\right)$. Meanwhile, the total of female $O$. 
waandersii caught was 54 individuals $/ \mathrm{m}^{2}$ with a maturity stage I (immature), maturity stage II (29 ind $/ \mathrm{m}^{2}$ ), maturity stage III (23 ind $\left./ \mathrm{m}^{2}\right)$, maturity stage IV ( $\left.8 \mathrm{ind} / \mathrm{m}^{2}\right)$, and maturity stage $\mathrm{V}\left(3 \mathrm{ind} / \mathrm{m}^{2}\right)$.

Male 0 . waandersii were found mostly in maturity stage I (immature) with the length ranging from $7.5-13.74 \mathrm{~cm}$. Furthermore, the length of fish found ranged from 11.25 $14.99 \mathrm{~cm}$ for those in maturity stage II, $12.5-16.24 \mathrm{~cm}$ for those in maturity stage III, $13.75-16.24 \mathrm{~cm}$ for those in maturity stage IV, and 15 - 16.24 for those in maturity stage V. Meanwhile, the length of female fish found ranged from 7.8 - $14.79 \mathrm{~cm}$ for those in maturity stage I (immature), $11.8-14.79 \mathrm{~cm}$ for those in maturity stage II, $11.8-14.8 \mathrm{~cm}$ for those in maturity stage III, $13.8-15.8 \mathrm{~cm}$ for those in maturity stage IV, and $14.8-15.8 \mathrm{~cm}$ for those in maturity stage $\mathrm{V}$.

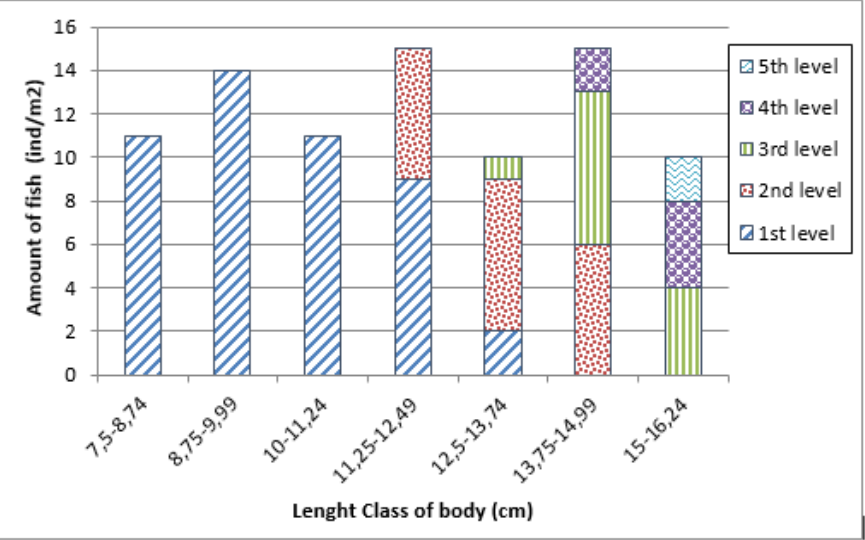

Figure 3a. The gonad maturity level of male 0 . waandersii

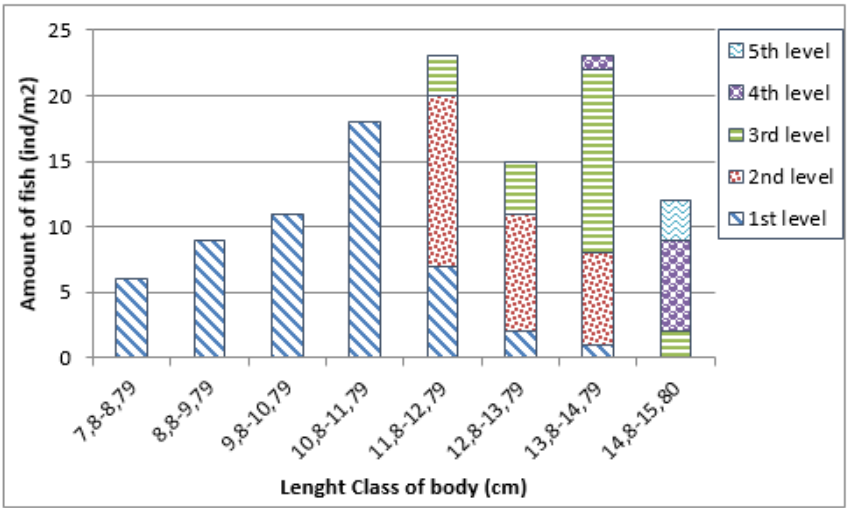

Figure 3b. The gonad maturity level of female $O$. waandersii

\section{Discussion}

\section{Condition Factor}

The average value of the relative weight (Wr) condition factor was 99.40 for male 0 . waandersii and 58.29 for female 0 . waandersii. These values 10 to be close to 100 , indicating that the environment is in a balanced state. The condition factor is the physiological condition of the fish, showing the fish obesity rate (Susanto \& Novitasari, 2017; Rahardjo \& Simanjuntak, 2008). The value of the condition factor can be calculated based on the equation of the relationship between length and weight of fish. Fish condition factor values can differ, which are influenced by the kind of species, availability of food sources, sex, age, and gonad maturity levels (Anibeze, 2000).

The condition factor is usually indicated as a "condition coefficient", denoted by ' $\mathrm{K}$ '. It is useful as a tool for diagnosing the physiological condition of fish in interacting with biotic and abiotic factors, as well as being used to monitor feed intensity, age, and fish growth rate (Ujjania et al., (2012); Kachari, (2017). The results of the Fulton's K condition factor calculation showed that the $\mathrm{K}$ value for male fish ranged from $0.42-3.43$ with an average of 1.05 , while that for female fish ranged from $0.59-3.67$ with an average of 1.47. Based on those values, it can be concluded that the average condition factor value of the female fish is greater than that of the male fish of the same size, meaning that the female fish tends to be bigger than the male. The gonad maturity condition supports this state. According to Jusmaldi et al., (2020), the condition factor is closely related to the number of fish with a mature gonad condition. Concerning this study, Jusmaldi et al., (2020) found different results from what the researchers found in this study. He discovered that male Osteochilus vittatus in the Benanga reservoir, East Kalimantan, is more significant than female Osteochilus vittatus, with an average of $1.18>$ 0.949 .

\section{Growth Pattern}

The obtained value regarding the growth pattern from male and female Osteochilus waandersii is classified in the harmful allometric category, meaning that the growth in length is faster than the growth in weight. Muchlisin et al. (2010) explained that the growth pattern of fish is influenced by several factors, including food availability and water conditions. They added that the behaviour of the fish influences the $b$ coefficient. Active swimming fish will show a lower b value compared to passive swimming fish. It is perhaps related to the allocation of energy expended for movement and growth. In general, fish will have $a b$ value ranging from 2 - 4 (Samat et al., 2008; Jamabo et al., 2009). Effendie (1979), stated that the high b value in fish is influenced by age, sex, gonad maturity level, and food. Food availability generally affects the length-weight relationship in fish (Ubamnata et al., 2017; Khairul, 2020).

A similar condition was also found by Rochmatin et al. (2014) in the Pening swamp, Semarang, with the b value of 2.8392. A study conducted by Putri et al. (2015) in Lake Telaga, Central Sulawesi, resulted in a b value of 2.838 and a negative allometric growth pattern. Meanwhile, Rochmatin et al. (2014), conducted a study on the Rawa swamp, Semarang, resulting in a b value of 2.839 and a negative allometric growth pattern. Furthermore, a different condition was found by Jusmaldi et al., (2020), in 
which they discovered that the $\mathrm{b}$ value for Osteochilus vittatus in the Benanga reservoir, East Kalimantan was 4.425 .

\section{Gonad Maturity Levels}

Table 3a showed that male 0 . waandersii caught was dominated by fish with an immature gonad level, totalling $54.65 \%$. Meanwhile, male fish with a mature gonad level ranged from $2.32-22.09 \%$. As shown in Table 3b, female 0 . waandersii caught was also dominated by fish with an immature gonad level, totalling $46.15 \%$. Meanwhile, female fish with a mature gonad level ranged from 2.56 - 24.8\%. From tables $3 \mathrm{a}$ and $3 \mathrm{~b}$, it can be concluded that the male $O$. waandersii caught with a mature gonad level are less than the female $O$. waandersii caught in the same gonad maturity level. A similar condition was also found in Osteochilus vittatus by Omar, (2010) in Lake Sidenreng, South Sulawesi.

The condition of $O$. waandersii which was in the maturity stage I (immature) during the study was carried out (November to January 2021) illustrates that the population of $O$. waandersii is on average at the stage towards the mature level. A similar situation was found by Sartika et al., (2015) on O. waandersii in the Rokan Kiri river, Riau, in which it was dominated by fish with a maturity stage I, totaling 42\%. Dewantoro et al., (2019) studied Osteochilus schlegelii in the Kapuas and Sekayam rivers, West Kalimantan, from March to August 2018. The result showed that fish with maturity stage I also dominated the catches with $81.08-100 \%$. (Nasution et al., 2006), studied Osteochilus kelabau in the Kampar river, Pelalawan, Riau, from February to October. They found that fish with the genus Osteochilus had gonad maturity peaks in October with synchronous reproduction patterns.

\section{Conclusion}

The growth patterns of male (1.944) and female (2.379) Osteochilus waandersii were in negative allometric category, meaning that the growth in length is faster than the growth in weight. This growth pattern indicates that there is an allegation of pressure or disturbance from environmental factors in the Tambatan river. Biological parameters show that the value of Fulton's condition factor was $0.42-3.43$ for male fish with an average of 1.05 and $0.59-3.67$ for female fish with an average of 1.47. The result of the observation on the gonad maturity level for male and female $O$. waandersii in the Tambatan river indicated that they were dominated by fish with a gonad maturity stage I (immature gonad level). This condition illustrates that the Waanders's hard-lipped barb (Osteochilus waandersii) was in the stage towards the mature level.

\section{Declaration statement}

The authors reported no potential conflict of interest.

\section{References}

Adlansyah, V., \& Samuel. (2017). Estimasi Parameter Pertumbuhan, dan Pola Rekruimen Ikan Paweh (Osteochilus hasselti) di Danau Diatas, Sumatera Barat. Seminar Nasional Tahunan XIV Hasil Penelitian Dan Kelautan, 83-91.

Anibeze, C. I. P. (2000). Length-weight relationship and relative condition of Heterobranchus lonifiles (Valencienness) from Idodo River, Nigeria. The ICLARM Quarterly, 23(2), 34-35. https://doi.org/10.1017/CB09781107415324.004

Atminarso, D., Samuel, S., Adjie, V., Adiansyah, S., Aprianti, S., Gautama, S. \&, \& Harahap, R. A. (2015). Ekobiologi dan Kajian Stok Ikan di Danau Kembar Provinsi Sumatera Barat. Laporan Teknis BP3U Palembang.xx hal.

Baird, I. G. (1998). Preliminary fishery stock assessment results from Ban Hang Khone, Khong District, Champasak Province, Southern Lao PDR. Technical Report. Center for Protected Areas and Watershed Management, Department of Forestry, Agriculture and Forestry Division, Champasak Province, Lao, People's Democratic Republic. 112 p.

Dewantoro, E., Yanto, H., Raharjo, E. I., \& Juniandy, A. L. (2019). Biology Aspect Of Kebali Fish (Osteochilus schlegelii ) From Kapuas River And Sekayam River , Kalimantan Barat. Jurnal Ruaya, 7(1), 70-78. http://dx.doi.org/10.29406/jr.v7i1.1320

EBiodiversity. (2015). Brings together Estonian wildlife data in one portal. http://elurikkus.ut.ee/. http://elurikkus.ut.ee/

Effendie, M. (1979). Metode Biologi Perikanan. Bogor Yayasan Dwi Sri.

Fishbase. (2021). Fishbase: A Global Information System of Fishes. https://www.fishbase.de/home.html

Hanel, L. and Novák, J. (2002). Czech names of animals V. Fish and vertebrate fish (Pisces) 3., small mouth (Gonorhynchiformes) - small fish (Cypriniformes). National Museum (zoological department), Prague.

Hayati, I., Efizon, D., \& Putra, R. M. (2018). Biologi Reproduksi Ikan Paweh (Osteochilus hasselti C.V) di Sungai Tarai Desa Tarai Bangun Kecamatan Tambang Kabupaten Kampar Provinsi Riau. 1-14.

Jamabo, N. A., Chindah, A. C., \& Alfred-Ockiya, J. F. (2009). Length-Weight Relationship of a Mangrove Prosobranch Tympanotonus fuscatus var fuscatus (Linnaeus, 1758) from the Bonny Estuary, Niger Delta, Nigeria. World Journal of Agricultural Sciences, 5(4), 384-388.

Jusmaldi, Hariani, N., \& Wulandari, N. A. (2020). Hubungan Panjang-Bobot Dan Faktor Kondisi Ikan Nilem (Osteochilus Vittatus Valenciennes, 1842) Di Perairan Waduk Benanga, Kalimantan Timur. Pusat Penelitian Biologi -LIPI Bogor, 8(1). 
Kachari, A. (2017). Length- Weight Relationship (LWR) and Condition Factor of Amblyceps apangi Nath and Dey From Arunachal Pradesh, India. Journal of Aquaculture Engineering and Fisheries Research, 3(3), 97-107. https://doi.org/10.3153/jaefr17013

Khairul. (2020). Kelas Ukuran dan Pola Pertumbuhan Helostoma temminckii ( Cuvier , 1829 ) di Kawasan Rawa Sungai Barumun, Kabupaten Labuhan Batu Selatan. Prosiding Seminar Biologi, 6(1), 239-242. https://doi.org/10.24252/psb.v6i1.15856

King, M. (1995). Fisheries Biology: Assessment and Management. Fishing New Books, Oxford.

Kottelat, M. Widjanarti, E. (2005). The fishes of Danau Sentarum National Park and the Kapuas Lakes area, Kalimantan Barat, Indonesia. Raffles Bull. Zool. Supplement. Raffles Bulletin of Zoology, 15(13), 139173.

Kottelat, M. K. (1998). Fishes of the Nam Theun and Xe Bangfai basins, Laos, with diagnoses of twenty-two new species (Teleostei: Cyprinidae, Balitoridae, Cobitidae, Coiidae and Odontobutidae). Ichthyol. Explor. Freshwater, 9(1), 1-128.

Kottelat, M. K., Whitten, A. J., \& Kartika Sari, S. P. dan Wirioatmojo, S. (1993). Ikan Air Tawar Indonesia Bagian Barat dan Sulawesi (Edisi Dwi Bahasa InggrisIndonesia). Jakarta: Periplus Ed. (ke dua). Periplus Ed.

Kottelat, M., Whitten, A. J., Kartikasari, S. N., \& Wirjoatmodjo, S. (1993). Osteochilus waandersii was reported from 7 countries/islands (Periplus E). Freshwater fishes of Western Indonesia and Sulawesi.

Morton, A., \& Routledge, R. D. (2006). Fulton's Condition Factor: Is it a Valid Measure of Sea Lice Impact on Juvenile Salmon? North American Journal of Fisheries Management, 26(1), 56-62. https://doi.org/10.1577/m05-068.1

Muchlisin, Z. A., Musman, M., \& Siti Azizah, M. N. (2010). Length-weight relationships and condition factors of two threatened fishes, Rasbora tawarensis and Poropuntius tawarensis, endemic to Lake Laut Tawar, Aceh Province, Indonesia. Journal of Applied Ichthyology, 26(6), 949-953. https://doi.org/10.1111/j.1439-0426.2010.01524.x

Nasution, S., Nuraini, \& Hasibuan, N. ' aini. (2006). Potensi akuakultur ikan kelabau (Osteochilus kelabau) Dari Perairan Kabupaten Pelalawan Propinsi Riau: Siklus Reproduksi. Prosiding Seminar Nasional Ikan IV, 301-308.

Omar, S. B. A. (2010). Aspek reproduksi ikan nilem, Osteochilus vittatus (Valenciennes, 1842). Jurnal Iktiologi Indonesia, 10(2), 111-122.

Putri, M. R. A., Sugianti, Y., \& Krismono, K. (2015). Beberapa Aspek Biologi Ikan Nilem (Osteochillus vittatus) Di Danau Talaga, Sulawesi Tengah. BAWAL Widya Riset

\section{Perikanan Tangkap, $\quad 7(2), \quad 111$ https://doi.org/10.15578/bawal.7.2.2015.111-120}

Rahardjo, M. F., \& Simanjuntak, C. P. H. (2008). Hubungan Panjang Bobot dan Faktor Kondisi Ikan Tetet, Johnius belangerii Cuvier ( Pisces: Sciaenidae) Di Perairan Pantai Mayangan, Jawa Barat. Jurnal IlmuIlmu Perairan Dan Perikanan Indonesia, 15(2), 135140.

Rainboth, W. J. (1996). Fishes of the Cambodian Mekong. FAO species identification field guide for fishery purposes. FAO.

Riede, K. (2004). Global register of migratory species - from global to regional scales. Final Report of the $R \& D$ Projekt 80805 081. Federal Agency for Nature Conservation, Bonn,

Rochmatin, S. Y., Solichin, A., \& Saputra, S. W. (2014). Aspek Pertumbuhan Dan Reproduksi Ikan Nilem (Osteochilus hasselti) Di Perairan Rawa Pening Kecamatan Tuntang Kabupaten Semarang. Management of Aquatic Resources Journal (MAQUARES), 3(3), 153-159. https://doi.org/10.14710/marj.v3i3.6667

Rypel, A. L., \& Richter, T. J. (2008). Empirical Percentile Standard Weight Equation for the Blacktail Redhorse. North American Journal of Fisheries Management, 28(6), 1843-1846. https://doi.org/10.1577/m07-193.1

Samat, A., Shukor, M. N., Arshad, A. G., \& Fatimah, A. (2008). Length-weight Relationship and Condition Factor of Pterygoplichthys pardalis (Pisces: Loricariidae) in Malaysia Peninsula. Research Journal of Fisheries and Hydrobiology, 3(2), 48-53.

Samuel, \&, \& Suryati, N. K. (2014). Parameters of growth, motality and fishing rate of bonylip barb (osteochilus waandersii) fish in Lake Kerinci, Jambi. Proceeding International Conference On Inland Fisheries, 73-80.

Sartika, D., Putra, R. M., \& Windarti. (2015). A Study on Reproductive Biology of Osteochilus wandersii from the Rokan Kiri River, Rokan Hulu Regency, Riau Province. Jurnal Online Mahasiswa, 2(2), 821-822. https://doi.org/10.15036/arerugi.44.821_2

Septian, T. M. S. ., Prayogo, H., \& Dirhamsyah, M. (2020). Keanekaragaman Jenis Ikan Famili Cyprinidae Di Sungai Ariung Kecamatan Putussibau Utara Kabupaten Kapuas Hulu. Jurnal Hutan Lestari, 8(2), 407-415. https://doi.org/10.26418/jhl.v8i2.40723

Soetignya, W. P., Munir, A. M. S., Hurriyani, Y., \& Anzani, Y. M. (2020). The reproductive biology of Waanders ' $s$ hard - lipped barb, Osteochilus waandersii in the Landak River, Indonesia. AACL Bioflux, 13(2), 640650.

Sukmono, T., \& Margaretha, M. (2017). Ikan air tawar di Ekosistem, Bukit Tiga Puluh (pertama). Yayasan konservasi ekosistem hutan Sumatra dan Frankfurt zoological society. 
Susanto, \& Novitasari, D. I. (2017). Struktur Umur dan Faktor Kondisi Ikan di Sungai Logawa Wilayah Kabupaten Banyumas. Sainteks, 14(1), 1-10. https://doi.org/10.30595/sainteks.v14i1.4186

Ubamnata, B., Diantari, R., \& and Hasani, Q. (2017). Kajian pertumbuhan ikan tembakang (Helostoma temminckii) di Rawa Bawang Latak Kabupaten Tulang Bawang, Lampung. Jurnal Penelitian Pertanian Terapan. Jurnal Penelitian Pertanian Terapan, 15(2), 90-99. https://doi.org/10.25181/jppt.v15i2.115

Ujjania, N. ., Kohli, M. P. S. and, \& Sharma, L. L. (2012). Length- weight relationship and condition factors of indian major carps (C. catla, L. rohita and C. mrigala) in Mahi Bajaj Sagar, India. Research Journal of Biology, 2(1), 30-36.

William, F., \& Beamish, H. (2006). Habitat characteristics of the cyprinidae in small rivers in Central Thailand. Environmental Biology of Fishes, 76(237), 237-253. https://doi.org/10.1007/s10641-006-9029-0

Wu, H., Shao, L. K. T., \& Lai, C. F. (1999). Latin-Chinese dictionary of fishes names. The Sueichan Press. 